RASĀYAN J. Chem.

Vol. 13 | No. 1 |772 - 779| January - March | 2020 ISSN: 0974-1496 | e-ISSN: 0976-0083 | CODEN: RJCABP

RJC http://www.rasayanjournal.com http://www.rasayanjournal.co.in

\title{
THE EFFECT OF NICKEL CONTENT IMPREGNATED ON ZEOLITE TOWARD CATALYTIC ACTIVITY AND SELECTIVITY FOR HYDROTREATING OF CASHEW NUT SHELL LIQUID OIL
}

\author{
M. L. Permata, W. Trisunaryanti*, I. I. Falah, M. T. Hapsari \\ and D. A. Fatmawati \\ Department of Chemistry, Faculty of Mathematics and Natural Sciences, \\ Universitas Gadjah Mada, Sekip Utara Bulaksumur Yogyakarta, 55281, Indonesia \\ *E-mail: wegats@ugm.ac.id
}

\begin{abstract}
This research aims to investigate the effect of various amount of $\mathrm{Ni}$ metal which is impregnated on Mordenite toward the catalytic activity of the Cashew Nut Shell Liquid Oil (CNSLO) hydrotreating process. The Ni/Mordenite catalysts were prepared by wet impregnation method using $\mathrm{Ni}\left(\mathrm{NO}_{3}\right)_{2} \cdot 6 \mathrm{H}_{2} \mathrm{O}$ with the $\mathrm{Ni}$ content varied under $1,3,5$ wt.\% and mordenite which were dissolved in methanol and carried out drying, calcination, and reduction. Hydrotreating is carried out in a semi-batch stainless steel reactor which is flowed with $\mathrm{H}_{2}$ gas. The catalyst was characterized and analyzed by Fourier Transform Infrared, X-Ray Diffractometer, Scanning Electron MicroscopeEnergy Dispersive X-Ray Spectrometer, Transmission Electron Microscopy, Gas Sorption Analyzer, and Atomic Absorption Spectrophotometer. The total acid amount test was carried out using ammonia vapor adsorption with the gravimetric method. The liquid product of hydrotreating was analyzed by Gas Chromatography-Mass Spectroscopy. Increasing the amount of metal impregnated on mordenite will increase the total acid site, activity, and selectivity of the gasoline fraction.
\end{abstract}

Keywords: Cashew Nut Shell Liquid Oil, Gasoline, Hydrotreating, Mordenite, Nickel

(C) RASĀYAN. All rights reserved

\section{INTRODUCTION}

Biomass is one of the abundant new and renewable energy sources, but its use is not optimal. Biomass can come from organic matter. ${ }^{1}$ Indonesia has a very high biomass potential and much of its natural wealth is needed to be used as an alternative material, one of which is cashew nut shell oil (Cashew Nut Liquid). Cashew nut shells contain about $50 \%$ of the oil known as Cashew Nut Shell Liquid (CNSL). ${ }^{2}$ CNSL itself is a complex phenolic compound with branch chains and is not saturated. The main content of this oil is anarchic acid of $70 \%$, cardol $18 \%$, and cardanol $5 \%^{3}$. This CNSL oil can be used as raw material for bioenergy production using the catalytic hydrocracking reaction method. This reaction will break long chains on CNSL into simple hydrocarbons. ${ }^{4}$

The hydrocracking process is one of the hydrotreating processes. Hydrocracking can be done in two ways. The first way is hydrocracking by heating hydrocarbon compounds at high temperatures ${ }^{5}$. The second way is hydrocracking with the help of a catalyst, and this method is seen as more efficient than using high temperatures. ${ }^{6}$ Bifunctional catalysts with two different active sites of metal and carriers are highly recommended for use in the hydrotreatment process because these two active sites can control hydrogenation and dehydrogenation reactions. ${ }^{7}$

The catalyst can affect the expected reaction speed of the product. The choice of catalyst to be used in the hydrocarbon process of long-chain hydrocarbons is important. ${ }^{8}$ Heterogeneous catalysts with two different active sites namely metal and carrier are highly recommended for use in the hydrotreatment process because they can control the hydrogenation and dehydrogenation reactions. ${ }^{9}$

Rasayan J. Chem., 13(1), 772-779(2020)

http://dx.doi.org/10.31788/RJC.2020.1315529 
RASĀYAN J. Chem.

Vol. 13 | No. 1 |772 - 779| January - March | 2020

Heterogeneous catalyst systems are preferred. After all, single metal catalysts do not have high thermal stability and will form agglomerations that can reduce surface area and are easily deactivated. Heterogeneous catalysts have acidic sites that provide cracking reactions and metal sides that provide hydrogenation/dehydrogenation processes. ${ }^{10}$ In research conducted by Da Costa-Serra et al. ${ }^{11}$, the presence of Ni metals on mordenite can increase Ni dispersion and prevent catalyst deactivation. Metal loading on mordenite can increase catalyst activity, and reduce coke formation. Mordenite can quickly deactivate due to its small porosity so that coke can cover the active site and even cover the pores of mordenite. Ni metal was chosen because it is a metal that has a cheap price, proven to have good catalytic activity due to its empty $\mathrm{d}$ orbitals that can increase Lewis acid site, and durable in the cracking process of ammonia. ${ }^{12}$

Trisunaryanti et al. ${ }^{12}$ explain that metal impregnation on materials such as zeolite will distribute the metal evenly on the carrier surface so that it will increase the specific surface area of the catalyst system as a whole. So it will add to the specific area of the system. Mesoporous based materials are widely used as carriers. The mesoporous system has a regular arrangement with a pore size distribution in the range of 2$50 \mathrm{~nm}^{13}$ In the previous study, the synthesis of Ni/Mordenite as a catalyst for hydrocracking of $\alpha$ cellulose was conducted. However, the effect of the amount of impregnated metal on mordenite has not been studied. ${ }^{12}$ Based on this explanation, the Ni/Mordenite catalyst was synthesized for the hydrotreating of the CNSL Oil, with a variable amount of metal impregnated on the Mordenite as its novelty. This study examines the effect of $\mathrm{Ni}$ metal loading on the total acidity of the catalyst, catalytic activity, liquid products produced through the hydraulic process and the characterization of the $\mathrm{Ni}$ /Mordenite catalyst.

\section{Materials}

\section{EXPERIMENTAL}

The CNSLO was obtained from the seed coat of cashew nuts in Bantul and press at the Jarak Lestari Cooperative in Cilacap, zeolite mordenite (HSZ 640-HOA) was purchased from Catalyst \& Chemical Ind.Co.Ltd., $\mathrm{Ni}\left(\mathrm{NO}_{3}\right)_{2} \cdot 6 \mathrm{H}_{2} \mathrm{O}$ were purchased from Merck, methanol $98 \%$ were purchased from SigmaAldrich, nitrogen and hydrogen gas was purchased from technical, PT. Samator Gas.

\section{Catalyst Preparation}

The Ni was impregnated on the Mordenite (Mor) and was prepared by the wet impregnation method using a salt precursor of $\mathrm{Ni}\left(\mathrm{NO}_{3}\right)_{2} \cdot 6 \mathrm{H}_{2} \mathrm{O}$. An $0.0495,0.1486$, and $0.2477 \mathrm{~g}$ of $\mathrm{Ni}\left(\mathrm{NO}_{3}\right)_{2} \cdot 6 \mathrm{H}_{2} \mathrm{O}$ respectively for $\mathrm{Ni}(\mathrm{A}) / \mathrm{Mor}, \mathrm{Ni}(\mathrm{B}) / \mathrm{Mor}$ and $\mathrm{Ni}(\mathrm{C}) /$ Mor mixed with $1.0 \mathrm{~g}$ the Mor in $50 \mathrm{~mL}$ of methanol, followed by evaporated at $27{ }^{\circ} \mathrm{C}$, then calcined $\left(20 \mathrm{~mL} / \mathrm{min}\right.$ of $\mathrm{N}_{2}$ flow) at $450{ }^{\circ} \mathrm{C}$ for $3 \mathrm{~h}$ and continued by reduction ( $20 \mathrm{~mL} / \mathrm{min}$ of $\mathrm{H}_{2}$ flow) for $3 \mathrm{~h}$ to produce $\mathrm{Ni} /$ Mor catalyst.

\section{Hydrotreating of CNSLO}

Hydrotreating conditions used include thermal (without catalyst) and catalytic (with $\mathrm{Ni}(\mathrm{A}) / \mathrm{Mor}$, $\mathrm{Ni}(\mathrm{B}) /$ Mor, and $\mathrm{Ni}(\mathrm{C}) /$ Mor catalysts). Catalyst and the CNSLO in a weight ratio of 1:50 were loaded in a stainless steel semi-batch reactor (1: $30 \mathrm{~cm}$, id: $1.6 \mathrm{~cm}$, od: $2 \mathrm{~cm}$ ). The reaction temperature was $450{ }^{\circ} \mathrm{C}$ for $2 \mathrm{~h}$ with $20 \mathrm{~mL} / \mathrm{min}$ of $\mathrm{H}_{2}$ flow. The reactor was connected with the condenser and the liquid product was collected in an ice-bath system and investigated by GC-MS.

The catalytic activity was measured by the gravimetric method consisted of liquid, gas, coke, and residue fractions.

$\begin{array}{ll}\text { Liquid }(\%) & : \text { (Mass of liquid/Mass of substrate) } \times 100 \\ \text { Coke }(\%) & : \text { (Mass of coke/ Mass of substrate) } \times 100 \\ \text { Residue (\%) } & : \text { (Mass of residue/ Mass of substrate) } \times 100 \\ \text { Gas }(\%) & :((\text { Mass of substrate - Mass of liquid - Mass of coke)/ Mass of the substrate) } \times 100 \\ \text { Total conversion }(\%) \quad:((\text { Mass of substrate - Mass of residue)/ Mass of substrate }) \times 100\end{array}$

The selectivity of the catalysts (\%) toward gasoline, diesel, $\geq \mathrm{C}_{18}$, alcohol, organic, and others was calculated from the GC-MS area (\%) multiple by weight percent of liquid fraction. 
RASĀYAN J. Chem.

Vol. 13 | No. 1 |772 - 779| January - March | 2020

\section{Detection Method}

The catalyst function group was characterized by an FTIR spectrometer (Shimadzu Prestige 21) at 4000$300 \mathrm{~cm}^{-1}$. The surface morphology of the catalyst was analyzed by SEM (JEOL JSM-6510) and TEM (JEM-1400). The amount of metal impregnated on the Mor was analyzed by EDX (JEOL JSM-6510) and Atomic Absorption Spectrophotometry (AAS) (Perkin Elmer 5110-PC). The pore characteristics of the catalysts were tested by using a Gas Sorption Analyzer (GSA) (Quantachrome Nova Win version 11.0). The crystallinity of catalysts was analyzed by XRD using a Philip's Expert MPD instrument. The total acid amount of the catalysts was tested by the gravimetric method using $\mathrm{NH}_{3}$ vapor adsorption. Acidity means the total acid amount (mmol) calculated from $\mathrm{NH}_{3}$ vapor absorbed on the surface of solid/gram solid multiple by the molecular weight of ammonia. The liquid product was analyzed by GC-MS.

\section{RESULTS AND DISCUSSION}

The functional groups contained in Mordenite before and after Ni impregnation at variation amount were analyzed by FTIR as presented in Fig.-1.

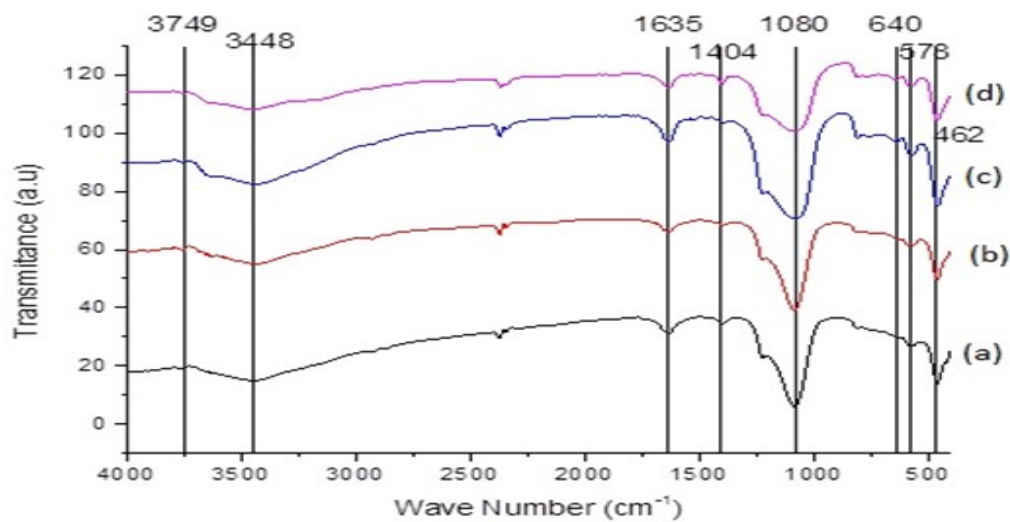

Fig.-1: FTIR Spectra of the: (a) Mor, (b) Ni(A)/Mor, (c) Ni(B)/Mor and (d) Ni(C)/Mor

Typical absorption bands for the Mor structures are found in wave numbers $1100-420 \mathrm{~cm}^{-1}$ which are vibrations of the external network group zeolite framework. ${ }^{14}$ Figure-1 shows that the Mor has the same absorption peak as the $\mathrm{Ni}(\mathrm{A}) / \mathrm{Mor}, \mathrm{Ni}(\mathrm{B}) / \mathrm{Mor}$ and $\mathrm{Ni}(\mathrm{C}) / \mathrm{Mor}$. This indicates that the functional groups on the Mor are not damaged due to the Ni metal loading process.

Characterization with SEM aims to determine the topography and morphology of the catalysts used. SEM images for the Mor and Ni/Mor catalysts are shown in Fig.-2. Based on the literature, a larger particle size indicates the formation of metals on the surface of mordenite. As reported by Mosayebi and Abedini ${ }^{15}$ that metal loading can change the particle size of the starting material, where mordenite produces particles larger than ZSM-5 and zeolite-Y.

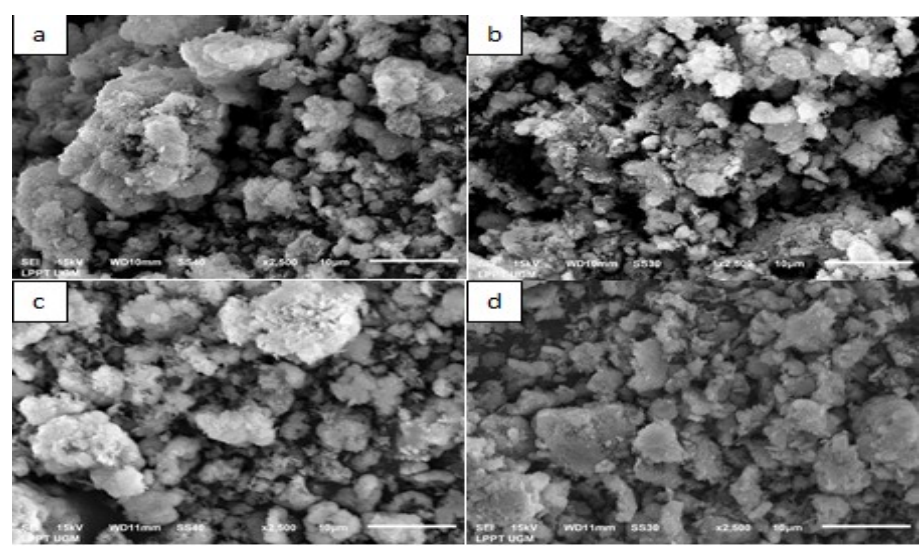

Fig.-2: SEM Image of the: (a)Mor, (b) Ni(A)/Mor (c) Ni(B)/Mor and (d) Ni(C)/Mor 
RASĀYAN J. Chem.

Vol. 13 | No. 1 |772 - 779| January - March | 2020

Figure-2 shows that there is no significant change in particle surface shape, but there is a narrowing of the pore with increased impregnated $\mathrm{Ni}$ metal content, this is also supported by the results of the characterization with GSA which can be seen in Table-1. In SEM images of Ni(A)/Mor (b), it can be seen that particles are larger than particles in the SEM images of Mor (a). The Ni metal in the Mor does not provide morphological changes compared to before impregnation. These results indicate that there is no change in the shape of crystals during the process of impregnation of $\mathrm{Ni}$ to Mor, this result is also supported by the results of characterization with XRD which can be seen in Fig.-6.

The characterization by TEM can be used to observe the morphology in a solid catalyst, it can also indicate the change in shape and its position in the use of a catalyst. Pores structure in the Mor can be seen in Fig.-3.

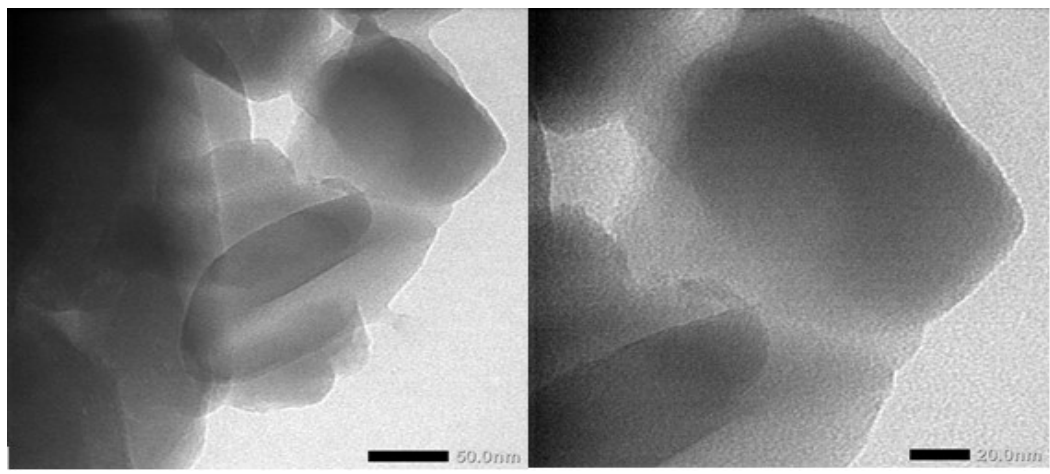

Fig.-3:TEM Images of the Mor

TEM images of the Mor provide information about the pore walls and hollow space of Mor. The pore walls of the Mor are shown in the dark part and the hollow spaces of the Mor are shown in the bright part. The bright part also indicates that the pores in the Mor refer to mesoporous size. ${ }^{16}$ Surface area, porevolume, pore diameter, total pore volume, and metal loading of the $\mathrm{Ni}(\mathrm{A}) / \mathrm{Mor}, \mathrm{Ni}(\mathrm{B}) / \mathrm{Mor}, \mathrm{Ni}(\mathrm{C}) / \mathrm{Mor}$ and the Mor can be seen in Table-1.

The result of the analysis with EDX, it can be known that there are three dominant elements in the Mor are $\mathrm{Si}, \mathrm{O}$, and $\mathrm{Al}$. After impregnation of 1,3 , and $5 \mathrm{wt} \%$ of the $\mathrm{Ni}$ metal shows that there are four elements are $\mathrm{Si}, \mathrm{O}, \mathrm{Al}$ and $\mathrm{Ni}$ with a percentage of the $\mathrm{Ni}$ metal is $1.41,2.16$, and $4.59 \mathrm{wt} \%$ respectively. The presence of Ni metal shows that the impregnation process of Ni metal on mordenite can be said to be successful. Based on the results of the analysis with AAS, impregnated $\mathrm{Ni}$ metal content at $\mathrm{Ni}(\mathrm{A}) / \mathrm{Mor}$, $\mathrm{Ni}(\mathrm{B}) /$ Mor, and $\mathrm{Ni}(\mathrm{C}) /$ Mor respectively are 1.09, 2.36, and $4.24 \mathrm{wt} . \%$. These results support the EDX analysis data of the amount of Ni carried on mordenite

Table-1: Catalysts Textural Properties

\begin{tabular}{c|c|c|c|c|c}
\hline Sample & $\begin{array}{c}\text { Surface Area } \\
\left(\mathrm{m}^{2} / \mathrm{g}\right)\end{array}$ & $\begin{array}{c}\text { Pore Volume } \\
(\mathrm{cc} / \mathrm{g})\end{array}$ & $\begin{array}{c}\text { Pore Diameter } \\
(\mathrm{nm})\end{array}$ & $\begin{array}{c}\text { Total Pore } \\
\text { Volume }(\mathrm{cc} / \mathrm{g})\end{array}$ & $\begin{array}{c}\text { Metal } \\
\text { Loading }\end{array}$ \\
\hline $\mathrm{Mor}$ & 280.389 & 0.025 & 3.563 & 0.170 & - \\
\hline $\mathrm{Ni}(\mathrm{A}) / \mathrm{Mor}$ & 223.484 & 0.020 & 3.223 & 0.139 & 1.091 \\
\hline $\mathrm{Ni}(\mathrm{B}) / \mathrm{Mor}$ & 164.354 & 0.019 & 3.513 & 0.111 & 2.366 \\
\hline $\mathrm{Ni}(\mathrm{C}) / \mathrm{Mor}$ & 251.747 & 0.021 & 3.212 & 0.153 & 4.247 \\
\hline
\end{tabular}

The surface area after metal impregnation will decrease. This may be caused by the metal being infused in the Mor not distributed evenly. Pore volume and diameter will be smaller after the impregnation of the metal because the metal that is injected has filled the pore on the catalyst so that reducing the pore diameter. The pore distribution of Mor, $\mathrm{Ni}(\mathrm{A}) / \mathrm{Mor}, \mathrm{Ni}(\mathrm{B}) / \mathrm{Mor}$ and $\mathrm{Ni}(\mathrm{C}) / \mathrm{Mor}$ can be seen in Fig.- 4 .

From Fig. 4 can be seen that there is a narrowing of the pore after the impregnation of the Ni metal. Figure-4 also shows that the pore distribution is not homogeneous, because Mor as a carrier has a nonuniform pore size and the amount of $\mathrm{Ni}$ embedded in the carrier material is also different. Solid adsorption/desorption isotherms are classified by their shape into six types. ${ }^{17}$ Solid adsorption/desorption isotherms can be seen in Fig.-5. 
RASĀYAN J. Chem.

Vol. 13 | No. 1 |772 - 779| January - March | 2020

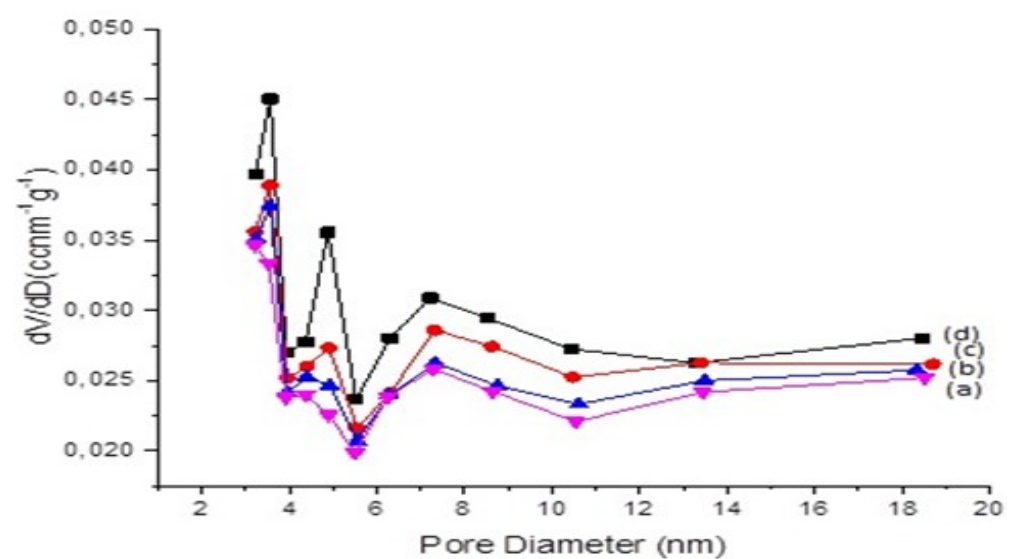

Fig.-4: Pore Diameter Distribution of Catalyst: (a) Ni(A)/Mor, (b) Ni(B)/Mor, (c) Ni(C)/Mor (c), and (d) Mor

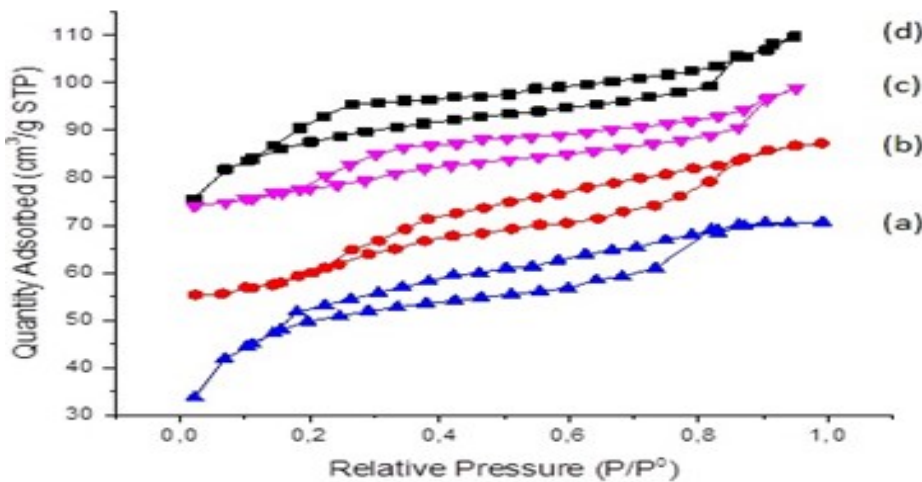

(d)

(c)

(b)

(a)

Fig.-5: Nitrogen Adsorption/Desorption Isotherms of: (a) Ni(B)/Mor, (b) Ni(A)/Mor, (c)Ni(C)/Mor, (d) Mor

Based on the isotherm adsorption-desorption graph literature obtained is type IV. Type IV is a typical isotherm for mesoporous solids and characterizes the marked hysteresis between the adsorption and desorption branches. ${ }^{18}$ Based on the literature the graph of the catalyst in Fig. -5 has hysteresis type 4 or H4. H4 loop type is a hysterical type for mesoporous material, this is by the character of the Mor which is a porous material ${ }^{19}$. Characterization with XRD aims to determine and compare the crystallinity of the catalyst both before and after the Ni metal is carried out. Diffractograms of the Mor, Ni(A)/Mor, $\mathrm{Ni}(\mathrm{B}) /$ Mor and $\mathrm{Ni}(\mathrm{C}) /$ Mor can be seen in Fig.-6.

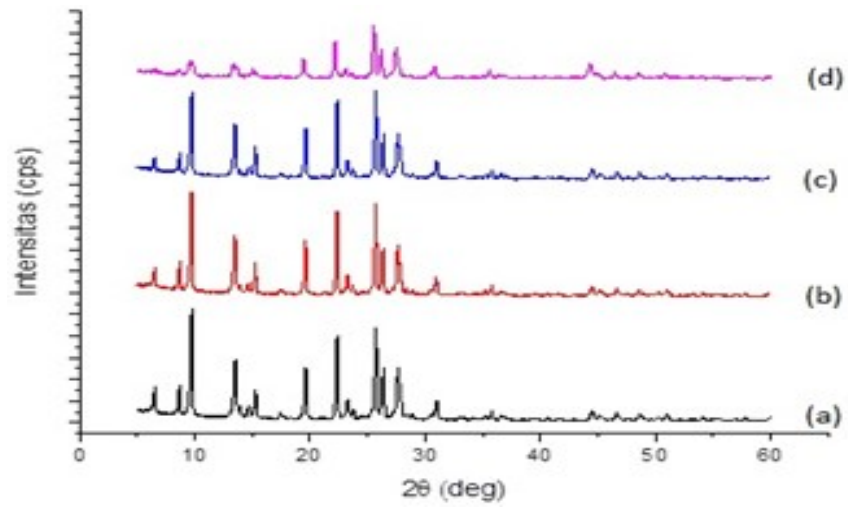

Fig.-6: Diffractogram of: (a) Mor, (b) Ni(A)/Mor (c) Ni(B)/Mor and (d) Ni(C)/Mor

Based on the Mor diffractogram shows the peaks at $2 \theta$ between $6-40^{\circ}$ which shows conformity to the Mor structure expressed by Treacy and Higgins. ${ }^{20}$ In Fig.- 6 it can be seen that the impregnation of metals onto the Mor does not damage the crystal structure of the Mor. The crystalline structure of metals impregnation on the Mor looks the same as the crystalline structure of the early material of the Mor, 
RASĀYAN J. Chem.

Vol. 13 | No. 1 |772 - 779| January - March | 2020

which shows that the crystallinity of the Mor does not change with impregnation of the Ni metal. Based on the result of the total acid amount of the Mor, $\mathrm{Ni}(\mathrm{A}) / \mathrm{Mor}, \mathrm{Ni}(\mathrm{B}) / \mathrm{Mor}$ and $\mathrm{Ni}(\mathrm{C}) / \mathrm{Mor}$ respectively were $5.729,7.751,9.038$ and $11.637 \mathrm{~mol} \mathrm{~g}^{-1}$. It showed that the Mor after being impregnated with the Ni metal had more total acidic amount than before metal impregnation. The Ni metal is a transition metal that has an empty d orbital degenerate so that it can act as a Lewis acid. The presence of these metals causes the bonds that can be formed between the catalyst and ammonia to increase as a result of increased total acid sites. Catalyst activity is mainly viewed from the amount of liquid product produced because it is this liquid product that contains high-value chemical compounds, so it is the main product of a hydrotreating reaction. The results of thermal and catalytic hydrotreating are presented in Table-2.

Tabel-2: Distribution of the CNSLO Hydrotreating Products

\begin{tabular}{c|c|c|c|c|c}
\hline \multirow{2}{*}{$\begin{array}{c}\text { Hydrotreating } \\
\text { Condition }\end{array}$} & \multicolumn{3}{|c|}{ Conversion (wt.\%) } & & Total Conversion \\
\cline { 2 - 6 } & Liquid Product & Gas Product & Residue & Coke & (wt.\%) \\
\hline Thermal & 40.01 & 59.9 & 14.02 & 0.9 & 85.98 \\
\hline Mor & 49.64 & 42.91 & 13.73 & 7.45 & 86.27 \\
\hline $\mathrm{Ni}(\mathrm{A}) /$ Mor & 51.55 & 45.43 & 3.25 & 3.02 & 96.75 \\
\hline $\mathrm{Ni}(\mathrm{B}) /$ Mor & 66.34 & 25.74 & 2.80 & 7.92 & 97.20 \\
\hline $\mathrm{Ni}(\mathrm{C}) /$ Mor & 73.50 & 23.55 & 1.87 & 2.95 & 98.13 \\
\hline
\end{tabular}

Table-2 shows that the hydrotreating thermal has more gas products compared to the catalytic hydrotreating since occurs through the mechanism of radical formation that is triggered by relatively high temperatures as described by Gates et al. ${ }^{21}$ The distribution of liquid products in catalytic hydrotreating is greater than thermal hydrotreating because it occurs through the mechanism of carbocation formation. The yield of the liquid product increases with the increase in acidity of the catalyst. TEM images of the $\mathrm{Ni}$ /Mor catalyst before and after hydrotreating can be seen in Fig.-7.

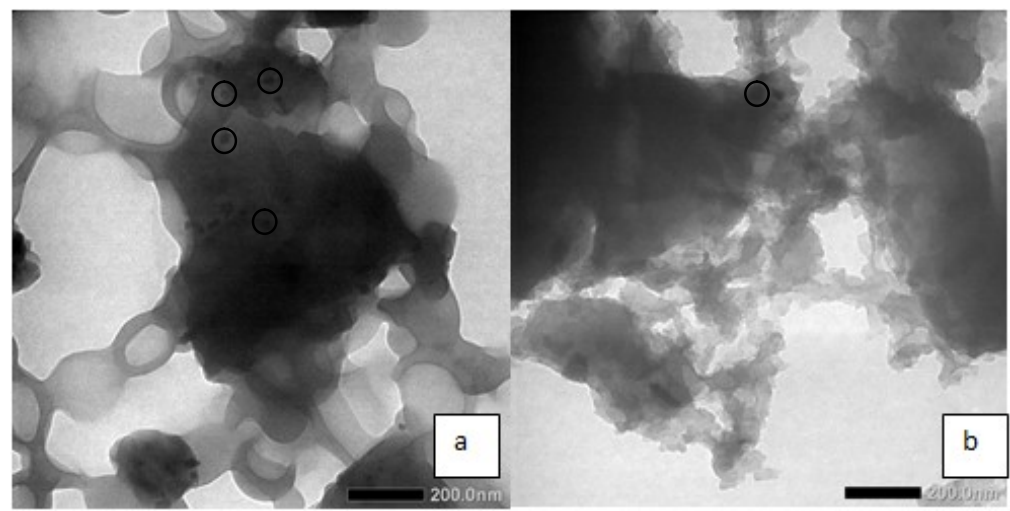

Fig.-7: TEM Image of (a)Ni(C)/Mor before and (b) Ni(C)/Mor after Hydrotreating

TEM image results capture the color of black dots on solid objects. Black spots are Ni metals impregnated on mordenite, so it can be seen that $\mathrm{Ni}$ metals have been impregnated on mordenite and fill the pores in mordenite. The success of impregnated metals can also be determined through SEM-EDX, XRD, and AAS characterization. Catalyst before hydrotreating there are still many pores after hydrotreating poreblocking occurs but not all pores are blocked, this shows that the $\mathrm{Ni}(\mathrm{C}) /$ Mor catalyst has good effectiveness ${ }^{22}$. Liquid products produced from hydrotreating thermal and catalytic were analyzed by GCMS to determine the selectivity of the liquid product fraction. The selectivity of CNSL oil hydrotreating liquid fraction can be seen in Table-3.

Table- 3 shows that the hydrotreating thermal and catalytic produces a greater fraction of gasoline compared to the diesel, organic and alcohol fractions. Gasoline is a hydrocarbon compound with several carbon atoms of 5 to $12\left(\mathrm{C}_{5}-\mathrm{C}_{12}\right)$, so that the fraction of gasoline is easier to enter the Mor pore which is relatively small compared to other larger fractions. Gasoline fraction produced by hydrotreating using $\mathrm{Ni}(\mathrm{C}) / \mathrm{Mor}>\mathrm{Ni}(\mathrm{B}) / \mathrm{Mor}>\mathrm{Ni}(\mathrm{A}) / \mathrm{Mor}>\mathrm{Mor}$. 
RASĀYAN J. Chem.

Vol. 13 | No. 1 |772 - 779| January - March | 2020

Tabel-3: Selectivity Catalysts towards the CNSLO Hydrotreating Product

\begin{tabular}{c|c|c|c|c|c|c}
\hline \multirow{2}{*}{$\begin{array}{c}\text { Hydrotreating } \\
\text { Condition }\end{array}$} & \multicolumn{5}{|c|}{ Fractions in a Liquid Product (wt.\%) } & \\
\cline { 2 - 7 } & Gasoline & Diesel & $\mathrm{C} \geq 18$ & Alcohol & Organic & Others \\
\hline Thermal & 13.59 & 11.23 & 1.12 & 8.21 & 4.85 & 1.01 \\
\hline $\mathrm{MOR}$ & 18.33 & 17.33 & 0.45 & 5.26 & 3.37 & 4.90 \\
\hline $\mathrm{Ni}(\mathrm{A}) / \mathrm{Mor}$ & 19.10 & 0.71 & 0.00 & 6.31 & 18.07 & 7.36 \\
\hline $\mathrm{Ni}(\mathrm{B}) / \mathrm{Mor}$ & 25.11 & 2.85 & 0.00 & 12.35 & 20.13 & 5.90 \\
\hline $\mathrm{Ni}(\mathrm{C}) /$ Mor & 30.02 & 0.33 & 0.00 & 14.02 & 20.11 & 9.02 \\
\hline
\end{tabular}

\section{CONCLUSION}

The increase in metal impregnated on Mor will increase the total acid site, activity, and selectivity of the catalyst for gasoline products. This is known based on the results and discussion.

i. The total acid sites Mor, $\mathrm{Ni}(\mathrm{A}) / \mathrm{Mor}, \mathrm{Ni}(\mathrm{B}) / \mathrm{Mor}$, and ni(C)/Mor are 5.729, 7.751, 9.038 and $11.637 \mathrm{~mol} \mathrm{~g}^{-1}$ respectively.

ii. The results of liquid products by thermal, Mor, $\mathrm{Ni}(\mathrm{A}) / \mathrm{Mor}, \mathrm{Ni}(\mathrm{B}) / \mathrm{Mor}, \mathrm{Ni}(\mathrm{C}) / \mathrm{Mor}$ are 40.01 , $49.64,51.55,66.34,73.50 \mathrm{wt} . \%$ respectively

iii. The results of gasoline fraction by thermal, Mor, Ni(A)/Mor, Ni(B)/Mor, Ni(C)/Mor are 13.59, $18.33,19.10,25.11,30.02 \mathrm{wt} . \%$ respectively

\section{ACKNOWLEDGMENT}

The authors thank Universitas Gadjah Mada for financial support of this work under the scheme of the RTA 2019 (Contract Number: No.3188/UNI/DITLIT/DIT-LIT/LT/2019).

\section{REFERENCES}

1. J.P. Muir, M.A. Sanderson, W.R. Ocumpaugh, R.M. Jones and R.L. Reed, Agronomy Journal, 93(4), 896(2001), DOI: 10.2134/agronj2001.934896x

2. K. Foger, Dispersed Metal Catalyst, University of Melbourne, Australia (1993).

3. R.N. Patel, S. Bandyopadhyay and A. Ganesh, Selective Extraction of Cardanol and Phenols from Cashew Nut Shell Liquid Obtained through Pyrolysis of Cashew Nut Shells, New Delhi (2005).

4. P.W. Atkins, Physical Chemistry, $7^{\text {th }}$ edition, Oxford University Press, Oxford (1994).

5. W. Trisunaryanti, P.S. Lisna, I. Kartini, Sutarno, I.I. Falah and Triyono, Asian Journal of Chemistry, 28(5), 997(2016), DOI:10.14233/ajchem.2016.19561

6. M. Pongsendana, W. Trisunaryanti, F.W. Artanti, I.I. Falah and Sutarno, Korean Journal of Chemistry Engineering, 34, 2591(2017), DOI:10.1007/s11814-017-0165-3

7. H. Kusumastuti, W. Trisunaryanti, I.I. Falah and M.F. Marsuki, Rasayan Journal of Chemistry, 2(11), 522(2018), DOI:10.31788/rjc.2018.1122061

8. I.B.P Mahardika, W. Trisunaryanti, Triyono, D.P. Wijaya and K. Dewi, Indonesian Journal of Chemistry, 17(3), 509(2017), DOI:10.22146/ijc.26561

9. M. Nurhadi, W. Trisunaryanti, M.U. Yahya and B. Setiaji, Indonesian Journal of Chemistry, 1(1), 7(2001), DOI: 10.22146/ijc.21954

10. A. Suseno, K. Wijaya, W. Trisunaryanti and Roto, Oriental Journal of Chemistry, 34(3), 1427(2018), DOI: $10.13005 /$ ojc/340332

11. J.F, Da Costa-Serra, M.T Navarro, F. Rey and A. Chica, Internasional Journal of Hydrogen Energy, 37, 7101(2012), DOI:10.1016/j.ijhydene.2011.10.086

12. W. Trisunaryanti, Triyono, R. Amrmunanto, L.P. Hastuti, D.D. Ristiana, and R.V. Ginting, Indonesian Journal of Chemistry, 18(1), 166(2018), DOI:10.22146/ijc.26491

13. K. Usui, K. Kidena, S. Murata, M. Nomura, and W. Trisunaryanti, Journal of Fuel, 83, 1899(2004), DOI: $10.1016 /$ j.fuel.2003.08.023

14. H.G Karge dan I.J Weitkamp, Chemie Ingenieur Technik, 58(120), 946(1986), DOI: 10.1002/cite. 330581206

15. A. Mosayebi, M.A. Mehrpouya, R. Abedini, Chemical Engineering Journal, 286, 416(2016), DOI: 10.1016/j.cej.2015.10.087 
RASĀYAN J. Chem.

Vol. 13 | No. 1 |772 - 779| January - March | 2020

16. X. Li, R. Prins, and J.A. Bokhoven, Journal of Catalysis, 262(2), 257(2009), DOI: 10.1016/j.jcat.2009.01.001

17. S.J. Gregg and K.W. Sing, Adsorption Surface Area, and Porosity, $2^{\text {nd }}$ edition, Academic Press, London (1982).

18. Y. Nishi and M. Inagaki, Material Science and Engineering of Carbon, 227(2016), DOI: 10.1016/B978-0-12-805256-3.00011-8

19. K.S.W. Sing, D.H. Everett, R.A.W. Haul, L. Moscou, R.A. Pierotti, J. Rouquerol and T. Siemienewska, Pure and Application Chemistry, 57(4), 603(1985), DOI: 10.1351/pac198557040603

20. M.M. Treacy and J.B. Higgins, Collection of Simulated XRD Powder Patterns for Zeolites, $4^{\text {th }}$ edition, New York (2001).

21. B.C. Gates, J.Z. Katzer and G.A. Schuit, Chemistry of Catalytic Process, $1^{\text {st }}$ edition, Mc Graw-Hill, New York (1995).

22. W. Trisunaryanti, E. Suarsih, Triyono, and I.I. Falah, 2019, Royal Society of Chemistry, 9, 1230(2019), DOI:10.1039/C8RA09034C

[RJC-5529/2018] 